\title{
Spatial simulation of forest road effects on soil erosion after fire
}

\author{
Longxi Cao ${ }^{1}$, William Elliot ${ }^{2}$, and Jonathan Long ${ }^{3}$ \\ ${ }^{1}$ Chengdu University of Science and Technology \\ ${ }^{2}$ USDA Forest Service Rocky Mountain Research Station \\ ${ }^{3}$ USDA Forest Service Pacific Southwest Research Station
}

June 22, 2020

\begin{abstract}
Post-fire managers throughout the world use predictive models to estimate potential erosion risks to aid in evaluating downstream impacts of increased runoff and erosion, and to target critical areas within a fire for applying mitigation practices. Erosion prediction can be complicated by forest road networks. Using GIS technology and a soil erosion model, this study evaluated the effect of roads on erosion and sediment yield following a wildfire, and whether the predictive models were providing reasonable results. The GeoWEPP model was used to simulate onsite erosion and offsite sediment delivery before and after fire disturbance. A $2-\mathrm{m}$ resolution DEM was used as the terrain layer. Erosion rates in excess of $4 \mathrm{Mg}$ ha- 1 yr-1 were predicted mainly from the moderate and high severity burn areas. Roads influenced both flow path and sub-catchment delineations, affecting the spatial distribution of sediment detachment and transport. Through that influence, roads tended to reduce estimated erosion on slopes below the roads, but road fillslopes and steep channels were areas of significant increases in erosion risks. Measured deposition amounts along roads and in sediment basins were similar to predicted amounts. The results confirm that road prisms, culverts and road ditches greatly influence sedimentation processes after wildfire, and they present opportunities to detain eroded sediments before they reach downstream water bodies.
\end{abstract}

\section{Spatial simulation of forest road effects on soil erosion after fire}

Longxi Cao $^{\text {A, B }}$, Visiting Scholar; William Elliot ${ }^{\text {B,D }}$, Research Engineer

USDA Forest Service, Rocky Mountain Research Station, Moscow, Idaho, USA

Jonathan W. Long C, Research Ecologist

USDA Forest Service, Pacific Southwest Research Station, Davis, California, USA

This study evaluated the effects of forest roads on soil erosion following a wildfire in a forest using GIS technology and a watershed soil erosion model. We found that roads could alter flow paths and reroute sediment, leading to deposition and reducing soil loss in a burned forest. WEPP-predicted sediment deposition on road surfaces and in sediment basins were similar to measured deposition.

The authors declare no conflicts of interest.

Running Title: Effect of Roads on Erosion after a Fire

\section{Acknowledgements}

This study was supported by the USDA Forest Service Pacific Southwest Research Station, using funds provided by the Bureau of Land Management through the sale of public lands as authorized by the Southern Nevada Public Land Management Act. It was also supported by the National Natural Science Foundation of China (Project 41571273 and 41807077), the China Scholarship Council (Project 201604910077). The 
authors also acknowledge the assistance in onsite data collection by Ina Sue Miller, a Hydrologist with the USDA Forest Service Rocky Mountain Research Station.

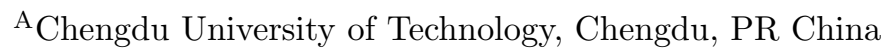

${ }^{B}$ USDA Forest Service, Rocky Mountain Research Station, Moscow, ID 83843, United States

${ }^{\mathrm{C}}$ USDA Forest Service, Pacific Southwest Research Station, Davis, CA 95616, United States

${ }^{\mathrm{D}}$ Corresponding author E-mail: welliot@moscow.com

\title{
Data Sharing
}

The data that support the findings of this study are available from the corresponding author upon reasonable request.

\begin{abstract}
Post-fire managers throughout the world use predictive models to estimate potential erosion risks to aid in evaluating downstream impacts of increased runoff and erosion, and to target critical areas within a fire for applying mitigation practices. Erosion prediction can be complicated by forest road networks. Using GIS technology and a soil erosion model, this study evaluated the effect of roads on erosion and sediment yield following a wildfire, and whether the predictive models were providing reasonable results. The GeoWEPP model was used to simulate onsite erosion and offsite sediment delivery before and after fire disturbance. A 2-m resolution DEM was used as the terrain layer. Erosion rates in excess of $4 \mathrm{Mg}$ ha $^{-1} \mathrm{yr}^{-1}$ were predicted mainly from the moderate and high severity burn areas. Roads influenced both flow path and sub-catchment delineations, affecting the spatial distribution of sediment detachment and transport. Through that influence, roads tended to reduce estimated erosion on slopes below the roads, but road fillslopes and steep channels were areas of significant increases in erosion risks. Measured deposition amounts along roads and in sediment basins were similar to predicted amounts. The results confirm that road prisms, culverts and road ditches greatly influence sedimentation processes after wildfire, and they present opportunities to detain eroded sediments before they reach downstream water bodies.
\end{abstract}

Additional Keywords: Soil Erosion; Watershed; Wildfire; Forest Roads; WEPP Modeling

\section{Introduction}

Soil erosion is one of the major concerns in forest management in forest watersheds everywhere. Disturbances such as forest roads, timber harvesting, and fire increase the likelihood of forest soil loss (Cornish, 2001; Croke, Mockler, Fogarty, \& Takken, 2005; Elliot, 2013; Hairsine, \& Grayson. 2003; Lane, Hairsine, Croke, \& Takken, 2006; Luce \& Black, 1999; Motha, Wallbrink, Sheridan \& Noske, 2007;). Eroded sediment that is routed to forest streams or lakes can degrade the aquatic environment (McCormick, Riemen, \& Kershner 2010) and impair beneficial uses of surface water resources (Elliot, 2013; Elliot, Miller, \& Enstice, 2016; Smith, Sheridan, Lane, Nyman, \& Haydon, 2011). Roads may accumulate, deliver, or increase sediment in runoff (Gucinski, Furniss, Ziemer, \& Brookes. 2001), increasing the complexity of understanding and evaluating soil erosion and sediment transport processes in post-fire forest conditions.

Fire disturbance in forests increases runoff and erosion generally due to the decrease of soil organic matter (Ebel, 2012), loss of ground cover and on some soils, the tendency for the upper soil layers to become water repellant (DeBano, 2000; Doerr, Shakesby, \& Walsh, 2000), all of which leave the soil more vulnerable to water erosion (Cerda \& Lasanta, 2005; Moody, Shakesby, Pierson, Robichaud, Spaeth \& Moffet, 2013; Robichaud, Cannon \& Martin, 2013; Robichaud Wagenbrenner \& Brown, 2010). Soil erosion following severe wildfire can be up to three magnitudes greater than before fire (DeBano, Neary \& Ffolliot, 1998; Elliot, 2013). At a watershed scale, sediment and runoff response to wildfire are often influenced by burn severity and the amount and intensity of precipitation (Robichaud, 2005). An intense rainfall event following a high burn severity fire can greatly increase runoff, erosion and downstream sedimentation (Robichaud, Beyers \& Neary, 2000; Moody et al., 2013). Topography is also a significant factor in post-fire soil erosion, with longer slopes and steeper slopes generating more sediment. 
Road construction may change the underlying topography and alter surface hydrology or interact with geomorphic processes (Gucinski et al., 2001; Reid, 2010; Wemple, Swanson \& Jones, 2001). Road networks linked with stream networks and may increase stream density within a watershed (Croke and Mockler, 2001; Gucinski et al., 2001; Wemple, Jones \& Grant, 1996). Forest roads can also decrease the critical gradient for gully initiation and reduce the distance between onsite sediment generation and downstream channels (Katz, Daniels \& Ryan, 2014). The road network may also increase watershed peak flow and sediment generation rates (Jones and Grant, 1996; Thomaz, Vestena \& Ramos Scharrón, 2014). On the other hand, road segments can act as hydrological barriers that can change the natural flow path. Roads with upslope drains intercept hillslope and upstream runoff that can accumulate along road surfaces before drainage through culverts or overtopping of the accumulated runoff across the road surface (Elliot 2004; Gucinski et al., 2001; Wemple, Clark, Ross \& Rizzo, 2017). Therefore flow accumulation and flow energy may be redistributed on hillslopes below road segments. This redistribution of runoff can result in altering surface soil erosion and sediment transport processes (Lane et al., 2006; Takken, Croke \& Lane, 2008).

With the aid of GIS technology and advanced modelling methods, many researchers addressed the influence of road networks on watershed scale hydrology and sediment processes (Akay, Erdas, Reis \& Yuksel, 2008; Araujo et al., 2014; Brooks, Boll, Deckert \& Elliot, 2006; Grace, 2017; Parsakho Lotfalian, Kavian, \& Hosseini, 2014; Soulis, Derkas \& Papadaki, 2014;). Most of these researchers stated that road networks would accelerate runoff accumulation processes and enhance peak flow and sediment generation in natural watersheds. However, following forest fires, in which large amounts of sediment are generated, downstream roads may change prefire flow routes, erosion, and sediment transport. For example, a road segment may intercept sediment flow and become a site for deposition (MacDonald and Coe, 2008; Wemple et al., 2001). This implies that the road effect on sediment transport in disturbed forests may be different from that in the undisturbed conditions. The road hydrology effect is difficult to be evaluated spatially as road topography cannot be precisely measured using a coarse DEM. However, a high-resolution LiDAR (Light Detection and Ranging) DEM can capture the topographical details for precise hydrologic analyses (Persendt and Gomez, 2016; Yang, Ames, Fonseca, Anderson, Shrestha, Glenn \& Cao, 2014;). The LiDAR DEM has also been used for road related flow path simulation (Sosa-Pérez and MacDonald, 2017). Thus it is possible with LIDAR data to characterize road-altered flow paths more precisely and estimate how road segments influence surface runoff and sediment transport in a montane watershed.

This study was carried out to evaluate the interactive effects of wildfire disturbance with roads on forest soil erosion. A GIS-based soil erosion model was applied to a fire-disturbed forest with internal roads. Sediment generation before and after the fire was calculated. The flow path network was delineated, and the spatial distribution of soil loss was estimated based on a high-resolution LiDAR DEM. The results of this study are intended to increase our understanding of how road segments influence surface runoff and post-fire sediment transport processes.

\section{Materials and methods}

\section{Study site description}

The study site was near the Emerald Bay on the southwest shore of Lake Tahoe in California, USA (Fig. 1); Latitude $38.94^{\circ} \mathrm{N}$, Longitude $120.08^{\circ} \mathrm{W}$. Vegetation is comprised of mixed conifer forest with significant areas covered by meadows, riparian areas, or bare granite outcrops (Coats, Larsen, Heyvaert, Thomas, Luck \& Reuter, 2008; Nevada Division of Environmental Protection, 2011). Lake Tahoe is the largest alpine lake in North America and has long been renowned for its exceptional clarity. However, erosion resulting from forest clearing and urban development over the past century and a half has degraded that clarity, leading to the establishment of a Total Maximum Daily Load for fine sediment particles, nitrogen, and phosphorus that are allowed to enter the lake (Nevada Division of Environmental Protection, 2011). The climate is comprised of wet winters and dry summers (Csb according to the Köppen classification; Ackerman, 1941). Average annual precipitation at the Echo Peak SnoTel station located $10 \mathrm{~km}$ south of the site is $1496 \mathrm{~mm}$ (NRCS, 2020). Site hydrology is dominated by rain-on-snow events (Brooks et al., 2016). Soil textures within the study area are dominated by a "gravelly loam coarse sand" derived from decomposed granite (Brooks, Dobre, Elliot, W, \& 
Boll, 2010; Lew, Dobre, Elliot, Robichaud, Brooks, Srivastava \& Frankenberger, 2020). For WEPP Modeling purposes, it was assumed to be a "sandy loam" in the WEPP soil database, for either forest, low severity, or high severity erodibility (Elliot, 2004), with relatively high hydraulic conductivity and rill erodibility for a given disturbance condition (unburned, low, moderate or high severity).

The Emerald Fire started early in the morning of October 14, 2016. Fueled by high winds (gusting up to 89 $\mathrm{km} \mathrm{h}^{-1}$ ), burning 71 ha (red boundary in Figure 1) by the following day, before heavy rainfall extinguished the fire (http://wildfiretoday.com/2016/10/14/200-acre-emerald-fire-at-lake-tahoe-slowed-by-rain). Precipitation depths of 81, 56, and $114 \mathrm{~mm}$ were recorded at the nearby Echo Peak SnoTel Site $10 \mathrm{~km}$ south of the fire on October 14, 15 and 16, respectively. (NRCS, 2020). Highway 89 (Road 1 in Figure 1) and another paved road (Cascade Road; Road 2 in Figure 1) pass through the northeast part of the burn site. According to our field survey, road 1 is flat without drains with the gradient of about 4 percent $\left(2.3^{\mathrm{o}}\right)$. Road 2 is crowned with drains on both sides, and a gradient of about 7 percent $\left(4.0^{\circ}\right)$. The burned area above and between the roads is generally uniform with an average gradient of about 40 percent $\left(21.8^{\circ}\right)$. The average gradient of hillslope below road 2 is about 17 percent $\left(9.6^{\circ}\right)$. There are 4 sediment basins installed to trap road sediment below road 2 (Figure 1).

In the days following the fire, the California Department of Transport removed a large amount of sediment that was deposited on Highway 89 (Road 1) in order to keep the road open. Eldorado County had to empty four sediment basins that had overtopped on cross drains below Cascade Road (Road 2; Vollmer, 2016).

Following the fire, a USDA Forest Service Burned Area Response (BAER) specialist evaluated the erosion risks using the Erosion Risk Management Tool (ERMiT; Robichaud, Elliot, Pierson, Hall, \& Moffet; Young, 2016). Stakeholders within the Tahoe Basin then asked the authors two questions: 1) What was the impact of the two roads on post fire erosion and sediment delivery? and 2) How accurate were the ERMiT erosion predictions? In order to answer these questions, it was necessary to develop some novel GIS and erosion modeling methods. A report was submitted to the stakeholders with our findings (Elliot et al., 2018). This paper presents the methodologies and findings related to surface erosion in that report.

Data collection and preparation

LiDAR terrain data were used to define flow paths and delineate the topography of roads in the study site. The LiDAR remote sensing data of Lake Tahoe were collected by Watershed Sciences, Inc. (WSI) in August 2010. The survey used two Leica ALS50 Phase II laser systems mounted in a Cessna Caravan 208B. The average first-return density of the delivered dataset was 11.82 points $\mathrm{m}^{-2}$ and the average ground return density was 2.26 points $\mathrm{m}^{-2}$. A raster elevation data set with a resolution of $0.5 \mathrm{~m}$ was created based on the ground return points from the LiDAR flight (Figure 1). We estimated soil burn severity using the differenced Normalized Burn Ratio (dNBR) from Landsat ETM 7 images from information before and after the fire to generate a Burned Area Reflectance Classification (BARC) layer (Parsons, Robichaud, Lewis, Napper \& Clark, 2010). The BARC data were classified following Parsons et al. (2010) to estimate soil burn severity (Table 1).

Michigan Technological Research Institute (MTRI) together with US Forest Service and NASA developed a rapid response tool to provide a 30-m digital elevation model, soil and land cover layers, and the linkage files necessary to run a spatial WEPP (Water Erosion Prediction Project) simulation of post-fire erosion (http://geodjango.mtri.org/geowepp/; Miller, Elliot, Billmire, Robichaud, \& Endsley, 2016). We uploaded the BARC raster map onto the MTRI main page, and then downloaded soil and land use files formatted for GeoWEPP (Miller, Billmire \& Banach, 2015) for the study site. The LANDFIRE Existing Vegetation Type (EVT) data downloaded from the Miller et al. (2015) server were adopted as the prefire land cover. Soil and land use data were provided as 30-m resolution raster files and stored in an ASCII format, including both pre-fire and post-fire conditions. The post-fire soil properties modification was achieved following the instructions described by Elliot and Hall (2010). We were then able to run the WEPP model spatially under different soil and land use types describing both pre-fire and post-fire conditions.

Erosion modeling 
The Water Erosion Prediction Project (WEPP) Model is a physically based soil erosion model (Laflen Elliot, Flanagan, Meyer \& Nearing, 1997), and is particularly suited to modeling the conditions common in forests (Elliot, 2013, Elliot \& Robichuad, 2001;). The accuracy of WEPP predictions, or predictions of any other erosion model, can be no greater than the accuracy of the input data. A study of 33 agricultural soils found the coefficient of variation of soil erodibility values, the mean divided by the standard deviation, was around 30 percent (Elliot, Liebenow, Laflen \& Kohl, 1989). Because of the natural variability of soils, Elliot, Hall and Scheele (2000) state that "The accuracy of a predicted runoff or erosion rate is, at best, plus or minus 50 percent" for a WEPP application for forest and rangeland erosion prediction. For predictions of erosion on burned forest hillslopes, Robichaud et al. (2007) have incorporated this variability into post fire erosion predictions in the Erosion Risk Management Tool (ERMiT) application of the WEPP model.

A geospatial application for the WEPP Model, the GeoWEPP ArcMap Wizard, allows users to import and utilize their own detailed terrain, soil and landuse information or to access publicly available spatial datasets (Flanagan, Frankenberger, Cochrane, Renschler, \& Elliot, 2013). The GeoWEPP model version 10.3 was adopted in the ArcGIS 10.3.1 environment for soil erosion modelling in the Emerald fire area. Topography, soil and landuse data were preprocessed before running the model to ensure the GIS projections were compatible. According to our results based on local terrain, the 0.5-m LiDAR DEM would likely generate too many flow paths, exceeding the maximum memory limitation in GeoWEPP running on a PC. Therefore the 0.5-m DEM was resampled as a 2-m DEM with the ArcMap Resample tool using the "Bilinear" method for hydrological process simulation and soil loss prediction. The 30-m resolution soil and landuse data were also resampled as 2-m raster files to be compatible with the 2-m DEM using the "Nearest" method to maintain consistent pixel values. The original downloaded soil data did not describe the road surface erodibility conditions, so the soil properties for the road surface pixels were revised to describe a paved road for those cells.

The GeoWEPP GIS wizard can be run in two modes, "watershed" and "flowpath." (Flanagan et al., 2013) When running in watershed mode, GeoWEPP lumps the shallow lateral flow, surface runoff and erosion response for each 2-10 ha hillslope polygon, and then routes the runoff and sediment through the stream network for each storm. The output from a watershed run is sediment loss and runoff for each hillslope and channel segment. In the flowpath mode, GeoWEPP estimates the erosion for each pixel in the DEM abstracting the erosion for that point from the distributed erosion predicted by the WEPP model. Each individual flowpath starts with a pixel adjacent to the channel and follows the flowpath up to the ridge from that pixel, draining an area of 0.2 to 0.5 ha. The flowpath method is not intended to be used to predict sediment delivery, but the output from a GeoWEPP flowpath run will include an average erosion rate for each hillslope polygon. The "flowpaths" as defined by GeoWEPP are not the same as the flow path lengths as defined by the ArcMap Spatial Analyst for routing runoff as described later, and although the GIS steps in their derivation are similar, they are not identical (Flanagan et al., 2013; http://desktop.arcgis.com/en/arcmap/)

GeoWEPP first delineates channel networks using the TOPAZ model (Flanagan et al., 2013). The TOPAZ model requires the user to specify a critical source area necessary for a channel to form. A critical source area (CSA) of 0.5 ha was necessary in order to generate a channel network to link most of the hillslopes within the Emerald fire area. For some hillslopes that were hydrologically independent from the adjacent areas, a CSA of 0.3 ha was used to generate more detailed channels to include these slopes. GeoWEPP then builds a watershed of hillslope sub-catchments and individual flow paths that, along with channel segment topography, serve as inputs to the WEPP Watershed version. Offsite sediment yields for both pre-fire and post-fire conditions in the study area were estimated based on sub-catchments (select "Watershed" as the GeoWEPP simulation method). For the post-fire run, a climate file was built for the year 2016 using the observed daily temperature and precipitation data from the Echo Peak SnoTel station. The pre-fire erosion modelling was carried out using long-term observed data from the same station and run for 20 years to simulate the normal forest conditions. For the purpose of evaluating the effect of road segments on post-fire surface flow accumulation and sediment transport, a flow path simulation was carried out and the onsite soil loss was estimated for each 2-m pixel. 


\section{Spatial and hydrological analysis methods}

GIS-based spatial analysis and digital terrain analyses were adopted to explore the spatial distribution of flow path and predicted onsite soil loss rates. The Spatial Analyst Tools distributed with ArcGIS 10.3.1 were used evaluate the effects of roads and other terrain features on flow directions, while the "flowpath" mode in GeoWEPP was used to estimate the erosion rate for each pixel. The ArcGIS hydrological analysis tool was adopted to calculate the upstream flow length for each pixel and delineate sub-catchment boundaries. The ArcGIS Buffer Wizard was applied to generate 10-m-width buffer belts in the downslope direction of the ridge and roads. There are 13 buffer belts below the ridge and 10 belts below each road segment. The WEPP onsite soil loss rate within each buffer belt was extracted to explore the spatial variation in the estimated soil erosion.

\section{Results}

\section{Soil erosion before and after wildfire}

The long-term simulation revealed that nearly 99 percent of the study area experienced an estimated average annual erosion rate less than $0.25 \mathrm{Mg} \mathrm{ha}^{-1}$ before the fire. When burned, erosion risk increased considerably (Figure 2). 77.6 percent of the burned area had predicted sediment yields greater than $4 \mathrm{Mg} \mathrm{ha}^{-1} \mathrm{yr}^{-1}$ (Table 2). After the fire, only 19 percent of the area had estimated sediment yields less than $0.25 \mathrm{Mg} \mathrm{ha}{ }^{-1}$. Table 2 shows the distribution of predicted post-fire sediment yield for different burn severities. The high and moderate severity categories account for 46 percent and 29 percent respectively of the total study area, but accounted for 86.8 percent of the highest erosion class. 56.3 percent of the highest sediment yield pixels $(>4$ $\mathrm{Mg} \mathrm{ha}^{-1} \mathrm{y}^{-1}$ ) were associated with the high burn severity. The low burn severity and unburned land account for 25 percent of the total area but only 13.2 percent of the area with a predicted erosion rates greater than $4 \mathrm{Mg} \mathrm{ha}^{-1} \mathrm{yr}^{-1}$. The low and unburned areas accounted for 67.8 percent of the total lowest sediment yield category $\left(<0.25 \mathrm{Mg} \mathrm{ha}^{-1} \mathrm{y}^{-1}\right)$ in the study area.

The underlying topography also influences the predicted soil erosion rates. (Figure 2) On long hillslopes the high erosion rates were predicted to extended beyond the fire boundary in some cases. Road segments intercepted the flow, constraining areas of high sediment yields. In some cases, the sediment yield levels in the patches below a road were lower than that of the adjacent hillslope segment above the road (Figure 2).

\section{Road segment effect on hydro-geomorphology characteristics}

Road-related flow paths were extracted with different CSA values and a detailed analysis was carried out on the effects of roads on predicted erosion rates. ArcMap flow paths that intersected with the upslope side road edges were recognized as inflow, and outflow paths were those that intersected with road edge on the downslope side (Table 3). As the CSA was reduced, the number of flow paths increased and the average distance between flow paths decreased. Table 3 shows that the number of outflow paths is always less than that of the inflow paths. This effect is especially noticeable for the smaller CSAs with more dense flow paths, where a larger portion of inflow paths are intercepted by road segments and result in relatively fewer outflow paths than that of the 1000- $\mathrm{m}^{2}$ CSA. Road 2, which falls below road 1 showed a lower density of outflow paths with a similar inflow density when CSA was $1000 \mathrm{~m}^{2}$. In the case of the $200 \mathrm{~m}^{2} \mathrm{CSA}$, the average distance between outflow paths for road 2 is more than twice the distance than that of the road 1 .

Further analyses were conducted to demonstrate road segment effect on surface hydrogeomorphic characteristics. Road segments that fall inside the burn boundary were chosen and the surrounding sub-catchments were delineated with the critical source area (CSA) of 0.5 ha (Figure 3). The hydrological units were then overlaid with the surface topography and road segments to determine the effects of roads on sub-catchment delineation. All sub-catchments in Figure 3 are connected to roads and can be classified as five types according to the spatial position with road segments (Table 4). There are 17 sub-catchments which pass through road segments and finally reach the fire boundary. These hydrologic units account for $47 \%$ of the total area. Small channel diversions were predicted when the sub-catchment channels intersected with road segments. On the other hand, $43 \%$ of the sub-catchments which started from ridge were intercepted and ended by the 
two road segments. In addition, 9 new hydrological units were formed downslope of road segments. In spite of being shorter, road 2 with its numerous drainage features, is more efficient than road 1 in intercepting upstream sub-catchments and generating new ones.

The effect of road segments on surface hydrological process was further studied in the context of flow length. Upstream flow length was overlaid with road segments (Figure 4). The highly detailed 2-m LiDAR DEM shows a large number of flow initial points (flow length $=0$, blue color) along the hillslope. This illustrates that road segments may stop the upstream flow length accumulation and start new flow paths below roads, depending on the road drainage features. Especially for road 2, which has ditches, most of the upstream flow paths were intercepted. For road 1, which has no ditches or culverts for most of its length, many upstream flow paths are not intercepted and pass over road 1 after a slight direction change. The flow then continues to accumulate length in the downslope direction.

\section{Road segment effect on soil loss prediction}

Figure 5 illustrates the GeoWEPP "Flowpath" mode simulated onsite soil loss for the study area under the post-fire conditions. The paved road surface showed minimal soil loss and can be distinguished from other areas with the yellow or green deposition or zero erosion categories. In some locations, deposition (yellow pixels) was predicted to occur on the road surface when a flow path reached a road segment. Detailed deposition on the surface of road 1 was simulated by running 22 different hillslope profiles that intersected with Road 1 in WEPP Windows. From these runs, the average annual sediment deposition along the road segment within the fire was calculated as $40.4 \mathrm{~kg} \mathrm{~m}^{-2}$, or a sediment deposition depth averaging $4 \mathrm{~cm}$ on the Road 1 surface.

To evaluate the surface hydrology unit effect on soil loss due to road influence, the onsite soil loss was classified into 6 categories and overlaid with sub-catchments. Table 5 shows that sub-catchments that originated from the ridge resulted in a larger fraction of the high soil loss category (greater than $4 \mathrm{Mg} \mathrm{ha}^{-1} \mathrm{yr}^{-1}$ ) than the sub-catchments below roads. The average soil loss rate also showed that sub-catchments below the main ridgeline had the greatest onsite soil loss. Similarly, the sub-catchments below roads showed relatively more deposition and much lower average soil loss rates than those above roads. For sub-catchments below road 2, the average predicted onsite soil loss was negative, indicating that deposition was the dominant process.

To explore soil erosion variation with terrain positions in more detail, the onsite soil loss rate for different distances from ridge and road segments were measured by buffer analysis. The predicted onsite soil loss rate was extracted for each 10-m-width belt, and then the average value was calculated and plotted with distance (Figure 6). It can be seen that the average onsite soil loss rate below ridge increased exponentially with the downslope distance. On the other hand, the average soil loss rates below both road 1 and road 2 showed a logarithmically declining trend with the downslope distance. The first 10-m buffer belt below roads showed remarkably higher soil loss rate compared to belts further below. The average onsite soil loss within the first 10 - $\mathrm{m}$ belt below road 1 is close to that of the last belt below the ridge. Similarly, the average onsite soil loss rate within the first belt below road 2 was similar to the last belt below road 1 . When the flow path goes beyond $50 \mathrm{~m}$ downslope from road 2, deposition tends to occur. This is consistent with the earlier results that measured erosion by sub-catchment and observations in the field. Note that the average onsite soil loss rate $70 \mathrm{~m}$ below road 2 (Figure 6.c) showed an abnormally low value due to the high deposition rates predicted within the channels. This low value was not included when developing the regression equation shown on the graph.

The GeoWEPP Watershed analysis divides the study area into hillslope polygons, each with a representative hillslope profile (Flanagan et al., 2013). From the GeoWEPP watershed outputs, one of the hillslope polygons that passed through road 1 was selected and run on its own in WEPP Windows to generate a typical soil loss graph along the hillslope profile (Figure 7). Figure 7 shows that the erosion rate generally increased as the slope length increased from 0 to $140 \mathrm{~m}$ due to runoff accumulation. When reaching the road segment, the erosion rate dramatically decreased and deposition occurred on the road surface section. As runoff exited the road and continued flowing downslope, soil loss rate increased sharply within a short distance below road 
segment, likely due to the steep fillslope and clearer water. The loss reached a maximum value for the profile, and then gradually declined as the increase in runoff due to increased slope length was offset by a decrease in the hillslope steepness.

\section{Comparing modeling results with other model predictions}

The original post-fire erosion analysis was carried out by a Forest Service Burned Area Emergency Response (BAER) specialist using the Erosion Risk Management Tool (ERMiT; Robichaud et al., 2007) to quickly estimate upland erosion following the Emerald Fire (Table 6; Young, 2016). Young (2016) followed recommended methods and only presented potential erosion from 2-, 5- and 10-year events, as the probability of a more severe event was unlikely. The three recorded precipitation events that occurred immediately following the wildfire $(81,56$, and $114 \mathrm{~mm})$ were similar to the 5 to 10 -year return period range of the ERMiT predictions for single storms (Table 6), if a rainfall event had been the cause of ERMiT's 10-y runoff event rather than rain-on-snow. Thus Young's (2016) selection of events was close to what actually occurred. We estimated a spatially averaged erosion rate of $16-25 \mathrm{Mg} \mathrm{ha}^{-1}$, depending on hillslope profile for the three observed storms. The ERMiT predictions for these three storms would be approximately one 2-y event $(0.22$ $\mathrm{Mg} \mathrm{ha} \mathrm{a}^{-1}$ ), one 5-y event $\left(6.15 \mathrm{Mg} \mathrm{ha}^{-1}\right)$ and one 10-y event (14.76 $\left.\mathrm{Mg} \mathrm{ha}^{-1}\right)$ for a total of about $21 \mathrm{Mg} \mathrm{ha}^{-1}$. Young's rapidly completed predictions, with a stated accuracy of plus or minus 50 percent, are similar to our more detailed analyses, confirming that the coarse-scale ERMiT predictions are reasonable for rapid post wildfire erosion analysis. The current BAER erosion prediction technologies as exemplified by Young (2016), however, did not consider the effects of roads in his analyses, which we have shown can be significant.

\section{Comparison of modelling results to observed sediment delivery}

Following the three October, 2016 rainfall events, a large amount of sediment was produced and accumulated on the surface of road 1, in constructed detention basins along road 2, and on the toe slopes downhill from the fire. Vollmer (2016) reported that $227 \mathrm{Mg}$ of sediment were removed from Road 1 following the three big storm events after the wildfire. The WEPP Windows modelling based on the 22 hillslope profiles intersecting Road 1 resulted in an estimated average deposition of $40.4 \mathrm{~kg} \mathrm{~m}^{-2}\left(404 \mathrm{Mg} \mathrm{ha}^{-1}\right.$ or an average depth of about 4-5 cm) on the road surface (Figures 5 and 7). The length of Road 1 within the fire is about $790 \mathrm{~m}$, and the width is about $8 \mathrm{~m}$. This means the total estimated deposition is $255 \mathrm{Mg}$, a number of similar magnitude to the amount of sediment removed.

We measured the total volume of the four sediment basins below road 2 to be $79.13 \mathrm{~m}^{3}$. The watershed topographies describing each of the sub-catchments above these sediment basins was entered into the WEPP Windows Watershed version, and the observed dimensions of each basin, assuming an "open" or weir type outlet was described in detail in the "Structures" file in the WEPP Windows Watershed Version interface. GeoWEPP delineated the watersheds above each of the sediment basins. For the observed climate, WEPP predicted that $139.6 \mathrm{Mg}$ of sediment needed to be removed from the sediment basins following the October, 2016 storms. The amount of sediment removed from these four basins was estimated to be $134 \mathrm{~m}^{3}$ (about 120 Mg; Personal Communication, R. Wigart, Stormwater Coordinator for the Tahoe Basin, Eldorado County, California, 13 December 2016). Although not a formal validation, these comparisons suggest that the WEPPpredicted erosion and deposition rates following wildfire are reasonable.

\section{Discussion}

\section{Road segment effect on surface flow pattern and soil loss}

Generally, the net effect of non-paved road networks in a forest was reported to increase basin-wide sediment production (Brooks et al., 2006; Soulis et al., 2014; Wemple et al., 2001;). Nevertheless, sediment deposition is also likely where sediment-laden overland runoff reaches low gradient road surfaces, (Finkner, Nearing, Foster \& Gilley, 1989; Gucinski et al., 2001; MacDonald and Coe, 2008). In post-fire conditions, Sosa-Pérez and MacDonald (2017) found that sediment deposits were much more likely on roads with gradients less than or equal to 5 percent. In this study, Road 1, the highway, had a gradient of about 4 percent, and experienced considerable deposition, whereas Road 2 had a gradient of 7 percent, and little deposition was observed in the 
road drains. The results in Table 3 and Figure 4 show that after the fire, road segments intercepted upstream runoff: and in Figures 5 and 7, were sites of sediment deposition. In the case of continuous upstream runoff accumulation along natural hillslopes, discharge is assumed to increase linearly and thus flow shear stress can be expressed as a function of downslope distance (Finkner et al., 1989). This explains the increasing soil loss rate below the ridge (Figures 6a and 7) and before the deposition on road surface (Figure 7).

Two processes account for the high onsite soil loss rate within the $10 \mathrm{~m}$ buffer belt below road segments (Figures $6 \mathrm{~b}$ and $\mathrm{c}$ ) and the sharp soil loss increase after leaving the road in Figure 7. First, with the large amount of post-fire sediment deposition along road surfaces, the increased flow below roads has a relatively low sediment concentration and therefore can detach more soil particles (Finkner et al., 1989). Secondly, the road segments have locally oversteepend fillslopes, because the excavated material uphill of the road centerline is placed downhill of the centerline. Further downhill, the slope decreases as does the predicted erosion rate, until ultimately, deposition begins to occur (Figure 5).

Figures 3, 4 and 5 all show different ways of seeing how a road can alter the boundary of sub-catchments and hydrological units on a post-fire landscape. Table 4 and Figure 3 show that a road segment can act as a boundary between sub-catchments, and in some cases, forming new sub catchments downhill from a road (Figure 4). The new sub catchments below roads tend to have shorter flow paths, and hence, are at less risk to concentrated flow erosion (Table 5). On the other hand, the flow length accumulation along roads in Figure 4 shows that road segments can also function as flow diverters, transporting sediment from one sub-catchment to a nearby sub-catchment. Road 2 is a good example of flow diversion as it has been identified as a channel in Figure 2, increasing the runoff and sediment yield from the adjacent subwatershed.

\section{The importance of road design}

Our results show the importance of the road drainage system in a post-fire watershed in altering surface hydrologic and soil loss processes. A field survey confirmed the LiDAR topography with road 1 flat and lacking culverts or an inside drainage ditch within the eastern part of the burnt area. Much of the upslope runoff either followed or crossed over the road surface, depositing sediment as it passed. Conversely, there were several ditches defined by the LiDAR DEM and verified by our field visit along road 2. Road-intercepted runoff was channeled along the ditches to culverts and downhill sediment basins rather than flooding over the road surface. Therefore the land surface below road 2 was not impacted by upslope runoff and the erosion risk was limited to channels which tended to be more armored than the burned hillslope (Figure 5). The upslope ditches and regularly spaced culverts on road 2 demonstrate the potential for road networks to reduce erosion risks in forests following wildfire.

\section{Implications for post-fire management}

In the absence of disturbance, upslope runoff and sediment generation are minimal. When forests are burned as in this study, surface runoff and soil erosion are greatly increased. As shown in Table 3, a large portion of uphill flow paths were stopped by road segments when intercepting the dense inflow than when intercepting the sparse ones. This implies that roads will be relatively more efficient in altering surface flow pattern under the post-fire conditions that generate more flow paths. By intercepting upstream runoff, road segments may prevent sediment transport to downstream channels. Sosa-Pérez and MacDonald (2017) observed that road segments could divert hillslope and road surface runoff to a single drainage point, thus reducing infiltration below the road. From this perspective, a road can act as a hydrologic barrier and reduce sediment yield in a fire disturbed forest (Gucinski et al., 2001). The ability of roads to manage overland flow means that conservation measures can be incorporated into road drainage sites. An example of these measures is the use of sediment basins installed below culverts on Road 2, making it unnecessary to treat the whole area below road 2 to limit erosion (Figures 2 and 5 ).

On the other hand, roads can intercept the high sediment loads that result from surface erosion from upslope burned areas as observed with Road 1. Sediment and other debris can accumulate and block ditches and culverts, leading to road damage and failures that compound the erosion (Foltz, Robichaud \& Rhee, 2009). The detailed WEPP results in Figure 2 showed high sediment yield near channel outlets below the road. In 
the watershed that included the Road 1 culvert near the junctions of Roads 1 and 2, channel erosion was predicted to be the source of 20 percent of the total sediment delivered from this watershed. Sediment basins, channel energy dissipation structures and in-channel grade control structures (Napper, 2006; Robichaud, Storrar and Wagenbrenner, 2019) may be beneficial to control erosion on such steep channels and to reduce the risk of gully initiation.

\section{Conclusions}

Through a GIS-based soil erosion model and high resolution LiDAR terrain data, this study provided a spatial analysis of road-related flow path delineation and soil loss in post-fire forest conditions. Fire greatly increased the soil erosion risk with estimated levels greater than $4 \mathrm{Mg} \mathrm{ha}^{-1} \mathrm{yr}^{-1}$ for nearly $80 \%$ of the burned area. Our model predictions conformed well with reported sediment depositions immediately following the fire. The modelling showed that even though roads are generally thought to exacerbate erosion problems, in the post-fire environment they had complex and variable effects on runoff and sediment transport. Overall the roads and downstream system of detention basins created opportunities to catch a considerable amount of sediment. In some cases, the roads diverted upland runoff and sediment to the adjacent subwatershed. The road fillslopes were predicted to be at risk for high onsite soil loss risk as were channels downstream of roads. The modeling and onsite observations suggest that a properly designed road drain system including well-spaced culverts with energy dissipating outlets can reduce the likelihood of water and sediment flooding over the road surface and minimize the risk of downstream channel erosion or gullying.

\section{Bibliography}

Ackerman, E.A. 1941. The Köppen classification of climates in North America. Geographical Review 31(1): 105-11.

Akay, A. E., Erdas, O., Reis, M., \& Yuksel, A. (2008). Estimating sediment yield from a forest road network by using a sediment prediction model and GIS techniques. Building and Environment , 43 , 687-695. https://doi.org/10.1016/j.buildenv.2007.01.047.

Araujo, H. A., Page, A., Cooper, A. B., Venditti, J., MacIsaac, E., Hassan, M. A., \& Knowler, D. (2014). Modelling changes in suspended sediment from forest road surfaces in a coastal watershed of British Columbia. Hydrological Processes , 28 , 4914-4927. https://doi.org/10.1002/hyp.9989.

Brooks, E. S., Boll, J., Elliot, W. J., \& Dechert, T. (2006). Global Positioning System/GIS-based approach for modeling erosion from large road networks. Journal of Hydrologic Engineering , 11 , 418-426. https://doi.org/10.1061/(ASCE)1084-0699(2006)11:5(418).

Brooks, E. S., Dobre, M., Elliot, W. J., Wu, J. Q., \& Boll, J. (2016). Watershed-scale evaluation of the Water Erosion Prediction Project (WEPP) model in the Lake Tahoe basin. Journal of Hydrology ,533 , 389-402. https://doi.org/10.1016/j.jhydrol.2015.12.004.

Cerdà, A., \& Lasanta, A. (2005). Long-term erosional responses after fire in the Central Spanish Pyrenees: 1. Water and sediment yield.Catena, 60 ,59-80. https://doi.org/10.1016/j.catena.2004.09.006.

Coats, R., Larsen, M., Heyvaert, A., Thomas, J., Luck, M., \& Reuter, J. (2008). Nutrient and sediment production, watershed characteristics, and land use in the Tahoe Basin, California-Nevada. Journal of the American Water Resources Association , 44, 754-770. https://doi.org/10.1111/j.1752-1688.2008.00203.x.

Cornish, P. M. (2001). The effects of roading, harvesting and forest regeneration on streamwater turbidity levels in a moist eucalypt forest.Forest Ecology and Management , 152 , 293-312. https://doi.org/10.1016/S0378-1127(00)00611-3.

Croke, J., \& Mockler, S. (2001). Gully initiation and road-to-stream linkage in a forested catchment, southeastern Australia. Earth Surface Processes and Landforms , 26 , 205-217. https://doi.org/10.1002/10969837(200102)26:2<205::AID-ESP168>3.0.CO;2-G. 
Croke, J., Mockler, S., Fogarty, P., \& Takken, I. (2005). Sediment concentration changes in runoff pathways from a forest road network and the resultant spatial pattern of catchment connectivity.Geomorphology , 68 , 257-268. https://doi.org/10.1016/j.geomorph.2004.11.020.

DeBano, L. F. (2000). The role of fire and soil heating on water repellency in wildland environments: a review. Journal of Hydrology , 231-232 , 195-206. https://doi.org/10.1016/S0022-1694(00)00194-3.

DeBano, L. F., Neary, D., \& Ffolliott, P. (1998). Fire's effects on ecosystems. (352 pp.) John Wiley \& Sons: New York.

Doerr, S. H., Shakesby, R. A., \& Walsh, R. P. D. (2000). Soil water repellency: Its causes, characteristics and hydro-geomorphological significance. Earth Science Reviews , 51 , 33-65. https://doi.org/10.1016/S00128252(00)00011-8.

Ebel, B. A. (2012). Wildfire impacts on soil-water retention in the Colorado Front Range, United States. Water Resources Research ,48, W12515, https://doi.org/10.1029/2012WR012362.

Elliot, W. J. (2004). WEPP Internet interfaces for forest erosion prediction. Journal of the American Water Resources Association ,40 , 299-309. https://doi.org/10.1111/j.1752-1688.2004.tb01030.x.

Elliot, W. J. (2013). Erosion processes and prediction with WEPP technology in forests in the Northwestern U.S. Transactions of the ASABE , 56 , 563-579. https://doi.org/10.13031/2013.42680.

Elliot, W. J., \& Hall, D. E. (2010). Disturbed WEPP Model 2.0. Ver. 2014.04.14. Moscow, ID: U.S. Department of Agriculture, Forest Service, Rocky Mountain Research Station. https://forest.moscowfsl.wsu.edu/fswepp/ .

Elliot, W. J., \& Robichaud, P. R. (2001). Comparing erosion risks from forest operations to wildfire. In: Procs of the International Mountain Logging and 11th Pacific Northwest Skyline Symposium. University of Washington, Seattle, WA. 78-89.

Elliot, W. J., Cao, L., Long, J. W., Dobre, M., Lew, R., Miller, M. E. 2018. Estimates of surface and mass erosion following the 2016 Emeral Wildfire, Final Report to the Late Tahoe West Shore Restoration Project. 27 pp. https://www.fs.fed.us/psw/partnerships/tahoescience/p101_elliot.shtml .

Elliot, W. J., Hall, D. E., \& Scheele D. L. 2000. Disturbed WEPP (Draft 02/2000) WEPP interface for disturbed forest and range runoff, erosion and sediment delivery, Technical Documentation. Online at $<$ https://forest.moscowfsl.wsu.edu/fswepp/docs/distweppdoc.html >. Accessed May 2020.

Elliot, W. J., Liebenow, A. M., Laflen, J. M. \& Kohl, K. D. 1989. A compendium of soil erodibility data from WEPP cropland soil field erodibility experiments 1987 \& 88. Report No. 3. W. Lafayette, IN: USDA-ARS, National Soil Erosion Research Laboratory. 316 pp.

Elliot, W. J., Miller, M. E., \& Enstice, N. (2016). Targeting forest management through fire and erosion modeling. International Journal of Wildland Fire, 25 : 876-887. https://doi.org/ 10.1071/WF15007.

Flanagan, D. C., Frankenberger, J. R., Cochrane, T. A., Renschler, C. S., \& Elliot, W. J. (2013). Geospatial application of the Water Erosion Prediction Project (WEPP) model. Transactions of the ASABE ,56 , 591-601. https://doi.org/10.13031/2013.42681.

Finkner, S. C., Nearing, M. A., Foster, G. R., \& Gilley, J. E. (1989). A simplified equation for modeling sediment transport capacity. Transactions of the ASAE , 32 , 1545-1550. https://doi.org/10.13031/2013.31187.

Foltz, R. B., Robichaud, P. R., \& Rhee, H. (2009). A synthesis of post-fire road treatments for BAER teams: methods, treatment effectiveness, and decision-making tools for rehabilitation.General Technical Report RMRS-GTR-228 . (pp. 152) Fort Collins, CO: U.S. Department of Agriculture, Forest Service, Rocky Mountain Research Station. 
Grace, III, J. M. (2017). Predicting forest road surface erosion and storm runoff from high-elevation sites. Transactions of the ASABE, 60 , 705-719. https://doi.org/10.13031/trans.11646.

Gucinski, H., Furniss, M. J., Ziemer, R. R., \& Brookes, M. H. (2001). Forest roads: a synthesis of scientific information. General Technical Report PNWGTR-509 . (pp. 103). Portland, OR: U.S. Department of Agriculture, Forest Service, Pacific Northwest Research Station.

Jones, J. A., \& Grant, G. E. (1996). Peak flow responses to clear-cutting and roads in small and large basins, western Cascades, Oregon. Water Resources Research, 32 , 959-974. https://doi.org/10.1029/95WR03493.

Katz, H. A., Daniels, J. M., \& Ryan, S. (2014). Slope-area thresholds of road-induced gully erosion and consequent hillslope-channel interactions. Earth Surface Processes and Landforms , 39 , 285-295. https://doi.org/10.1002/esp.3443.

Laflen, J. M., Elliot, W. J., Flanagan, D. C., Meyer, C. R., \& Nearing, M. A. (1997). WEPP-Predicting water erosion using a process-based model. Journal of Soil and Water Conservation, 52, 96-102.

Lane, P. N. J., Hairsine, P. B., Croke, J. C., \& Takken, I. (2006). Quantifying diffuse pathways for overland flow between the roads and streams of the mountain ash forests of central Victoria Australia.Hydrological Processes, 20 , 1875-1884. https://doi.org/10.1002/hyp.5940.

Lew, R. Dobre, M., Elliot, W., Robichaud, P., Brooks, E., Srivastava, A., \& Frakenberger, J. 2020. WEPP Cloud: Lake Tahoe. https://wepp1.nkn.uidaho.edu/weppcloud/lt/ . Accessed June 2020.

Luce, C, \& Black, T. (1999). Sediment production from forest roads in western Oregon. Water Resources Research , 35 , 2561-2570. https://doi.org/10.1029/1999WR900135

MacDonald, L. H., \& Coe, D. B. R. (2008). Road sediment production and delivery: processes and management. In: Proceedings of the First World Landslide Forum, International Programme on Landslides and International Strategy for Disaster Reduction . (pp. 381-384). United Nations University, Tokyo, Japan.

McCormick, F. H., Riemen, B. E., \& Kershner, J. L. (2010). Biological responses to stressors in aquatic ecosystems in Western North America: Cumulative watershed effects of fuel treatments, wildfire, and postwildfire remediation. Chapter 11. IN Elliot, W. J., Miller, I. S., \& Audin, L. eds. Cumulative Watershed Effects of Fuel Management in the Western United States. General Technical Report RMRS-GTR-231. (pp. 206-233). Fort Collins, CO: U.S. Department of Agriculture, Forest Service, Rocky Mountain Research Station.

Miller, M. E., Billmire, M., \& Banach, D. (2015). NASA BAER user manual for running GeoWEPP. (pp. 21) http://geodjango.mtri.org/geowepp/

Miller, M. E., Elliot, W. J., Billmire, M., Robichaud, P. R., \& Endsley, K. A. (2016). Rapid response tools and datasets for post-fire remediation: Linking remote sensing and process-based hydrologic models.International Journal of Wildland Fire, 25 , 1061-1073. https://doi.org/10.1071/WF15162.

Moody, J. A., Shakesby, R. A., Robichaud, P. R., Cannon, S. H., \& Martin, D. A. (2013). Current research issues related to post-wildfire runoff and erosion processes. Earth-Science Reviews , 122 , 10-37. https://doi.org/10.1016/j.earscirev.2013.03.004.

Motha, J. A., Wallbrink, P. J., Hairsine, P. B., \& Grayson, R. B. (2003). Determining the sources of suspended sediment in a forested catchment in southeastern Australia. Water Resources Research ,39, 1056. https://doi.org/10.1029/2001WR000794.

Napper, C. (2006). Burned area emergency response treatments catalogue. 0625 1801-SDTDC. (pp. 266) San Dimas, CA: USDA Forest Service, Sand Dimas Technology and Development Center.

Natural Resources Conservation Service (NRCS). 2020. National Water Climate Center, Echo Peak SnoTel Site.https://wcc.sc.egov.usda.gov/nwcc/site?sitenum=463. Accessed June 2020. 
Nevada Division of Environmental Protection. (2011). Final Lake Tahoe Total Maximum Daily Load. (pp. 339)https://archive.epa.gov/region09/water/archive/watershed/tahoe/pdf/final-lake-tahoetmdl.pdf,Carson City, NV.

Parsakhoo, A., Lotfalian, M., Kavian, A., \& Hosseini, S. A. (2014). Prediction of the soil erosion in a forest and sediment yield from road network through GIS and SEDMODL. International Journal of Sediment Research , 29 , 118-125. https://doi.org/10.1016/S1001-6279(14)60027-5.

Parsons, A., Robichaud, P. R., Lewis, S. A., Napper, C., \& Clark, J. T. (2010). Field guide for mapping post-fire soil burn severity. General Technical Report RMRS-GTR-243 . (pp. 49). Fort Collins, CO: Rocky Mountain Research Station.

Persendt, F. C., \& Gomez, C. (2016). Assessment of drainage network extractions in a low-relief area of the Cuvelai Basin (Namibia) from multiple sources: LiDAR, topographic maps, and digital aerial orthophotographs. Geomorphology , 260 , 32-50. https://doi.org/10.1016/j.geomorph.2015.06.047.

Pierson, F. B., Robichaud, P. R., Spaeth, K. E., \& Moffet, C. A. (2003). Impacts of fire on hydrology and erosion in steep mountain big sagebrush communities. Renard, K. G., McElroy, S. A., Gburek, W. J., Canfield, H. E., Scott, R. L. (Eds.), First Interagency Conference on Research in the Watershed (pp. 625-630). October 27-30, 2003, U.S. Department of Agriculture, Agricultural Research Service.

Reid, L. M. (2010). Cumulative effects of fuel treatments on channel erosion and mass wasting. Chapter 10. IN Elliot, W. J., Miller, I. S., \& Audin, L. (Eds). Cumulative Watershed Effects of Fuel Management in the Western United States. General Technical Report RMRS-GTR-231 . (pp. 101-125). Fort Collins, CO: U.S. Department of Agriculture, Forest Service, Rocky Mountain Research Station.

Robichaud, P. R. (2005). Measurement of post-fire hillslope erosion to evaluate and model rehabilitation treatment effectiveness and recovery.International Journal of Wildland Fire , 14 , 475-485. https://doi.org/ 10.1071/WF05031.

Robichaud, P. R., Beyers, J. L., \& Neary, D. G. (2000). Evaluating the effectiveness of postfire rehabilitation treatments. General Technical Report RMRS-GTR-63 . (pp. 85). Fort Collins, CO: U.S. Department of Agriculture, Forest Service, Rocky Mountain Research Station.

Robichaud, P. R., Elliot, W. J., Pierson, F. B., Hall, D. E., \& Moffet, C. A. (2007). Predicting postfire erosion and mitigation effectiveness with a web-based probabilistic erosion model. Catena , 71 , 229-241. https://doi.org/10.1016/j.catena.2007.03.003.

Robichaud, P. R., Storrar, K. A. \& Wagenbrenner, J. W. (2019). Effectiveness of straw bale check dams at reducing post-fire sediment yields from steep ephemeral channels. Science of the Total Environment 676 (2019), 721-731. https://doi.org/10.1016/j.scitotenv.2019.04.246

Robichaud, P. R., Wagenbrenner, J. W., \& Brown, R. E. (2010). Rill erosion in natural and disturbed forests: 1. Measurements. Water Resources Research , 46 , W10506. https://doi.org/10.1029/2009WR008314.

Sheridan, G. J., \& Noske, P. J. (2007). Catchment-scale contribution of forest roads to stream exports of sediment, phosphorus and nitrogen.Hydrological Processes , 21 , 3107-3122. https://doi.org/10.1002/hyp.6531.

Smith, H. G., Sheridan, G. J., Lane, P. N. J., Nyman, P., \& Haydon, S. (2011). Wildfire effects on water quality in forest catchments: A review with implications for water supply. Journal of Hydrology ,396 , 170-192. https://doi.org/10.1016/j.jhydrol.2010.10.043.

Sosa-Perez, G., \& MacDonald, L. H. (2017). Wildfire effects on road surface erosion, deposition, and road-stream connectivity. Earth Surface Processes and Landforms , 42 , 735-748. https://doi.org/10.1002/esp.4018.

Soulis, K. X., Dercas, N., \& Papadaki, C. H. (2015). Effects of forest roads on the hydrological response of a small-scale mountain watershed in Greece. Hydrological Processes , 29 , 1772-1782. 
https://doi.org/10.1002/hyp.10301.

Takken, I., Croke, J., \& Lane, P. (2008). Thresholds for channel initiation at road drain outlets. Catena , 75, 257-267. https://doi.org/10.1016/j.catena.2008.07.001.

Thomaz, E. L., Vestena, L. R., \& Ramos Scharron, C. E. (2014). The effects of unpaved roads on suspended sediment concentration at varying spatial scales - a case study from Southern Brazil. Water and Environment Journal , 28 , 547-555. https://doi.org/10.1111/wej.12070.

Vollmer, M. (2016). Emerald fire update. Presentation to Tahoe Regional Planning Authority Advisory Planning Commission on 8 November, 2016.

Wemple, B. C., Swanson, F. J., \& Jones, J. A. (2001). Forest roads and geomorphic process interactions, Cascade Range, Oregon. Earth Surfaces Processes and Landforms , 26, 191-204. https://doi.org/10.1002/10969837(200102)26:2<191: AID-ESP175>3.0.CO;2-U.

Wemple, B. C., Jones, J. A., \& Grant, G. E. (1996). Channel network extension by logging roads in two basins, western Cascades, Oregon.Water Resources Bulletin , 32 , 1195-1207. https://doi.org/10.1111/j.1752-1688.1996.tb03490.x.

Wemple, B. C., Clark, G. E., Ross, D. S., \& Rizzo, D. M. (2017). Identifying the spatial pattern and importance of hydro-geomorphic drainage impairments on unpaved roads in the northeastern USA.Earth Surfaces Processes and Landforms , 42 , 1652-1665. https://doi.org/10.1002/esp.4113.

Yang, P., Ames, D. P., Fonseca, A., Anderson, D., Shrestha, R., Glenn, N. F., \& Cao, Y. (2014). What is the effect of LiDAR-derived DEM resolution on large-scale watershed model results? Environmental Modelling 85 Software , 58 , 48-57. https://doi.org/10.1016/j.envsoft.2014.04.005.

Young, D. (2016). BAER assessment soils report - Emerald Fire. (pp. 13). Redding, CA: U.S. Department of Agriculture, Forest Service, Region 5, Shasta-Trinity National Forest. 13p.

Tables

Table 1. Distribution of estimated soil burn severity categories after the Emerald fire

\begin{tabular}{llll}
\hline Burn Severity & dNBR range & Area (ha) & Percent (\%) \\
\hline Unburned & {$[?] 99$} & 9.43 & 13.28 \\
Low Severity & $100-269$ & 8.25 & 11.62 \\
Moderate Severity & $270-659$ & 20.65 & 29.08 \\
High Severity & {$[?] 660$} & 32.67 & 46.01 \\
\hline
\end{tabular}

Table 2. Predicted post-fire sediment yield under different burn severities

\begin{tabular}{lll}
\hline Sediment yield $\left(\mathrm{Mg} \mathrm{ha}^{-1} \mathrm{yr}^{-1}\right)$ & Area under different burn severities $(\text { ha })^{+}$ & Area under different burn severities $(\mathrm{ha}){ }^{+}$ \\
\hline & Unburned & Low \\
$0-0.25$ & 4.95 & 3.31 \\
$0.25-1$ & 0.66 & 0.08 \\
$1-2$ & 0.43 & 0.52 \\
$2-4$ & 0.10 & 0.14 \\
$>4$ & 3.20 & 4.03 \\
\hline
\end{tabular}

+ The total area modeled with GeoWEPP is slightly smaller than Table 1 as channel areas are not included in GeoWEPP hillslopes 
Table 3. Description of road related flow paths with different CSA values

\begin{tabular}{lllll}
\hline Type of flow paths & Flow path CSA $=1000 \mathrm{~m}^{2}$ & Flow path CSA $=1000 \mathrm{~m}^{2}$ & Flow path CSA $=400 \mathrm{~m}^{2}$ & Flow path CS \\
& Number & DBF $(\mathrm{m})$ A & Number & 88 \\
Flow into road 1 & 44 & 20.91 & 58 & 10.45 \\
Flow out of road 1 & 41 & 22.44 & 35 & 15.86 \\
Flow into road 2 & 23 & 20.52 & 17 & 13.49 \\
Flow out of road 2 & 15 & 31.47 & 27.76 \\
\hline
\end{tabular}

+ DBF stand for the average distance between flow paths which was calculated as road length divided by the flow path number.

Table 4. Description of road related sub-catchments

\begin{tabular}{llll}
\hline Type of sub-catchments & Number & Area (ha) & Area ratio (\%) \\
\hline From ridge and reach fire boundary & 17 & 14.85 & 46.96 \\
From ridge and ended by road 1 & 1 & 1.31 & 4.15 \\
From ridge and ended by road 2 & 10 & 12.26 & 38.77 \\
From road 1 and reach fire boundary & 3 & 0.90 & 2.84 \\
From road 2 and reach fire boundary & 6 & 2.30 & 7.28 \\
\hline
\end{tabular}

Table 5. Onsite soil loss rate in different types of sub-catchments

\begin{tabular}{|c|c|c|c|c|c|c|c|c|c|}
\hline $\begin{array}{l}\text { Soil loss } \\
\text { rate }(\mathrm{Mg} \\
\left.\mathrm{ha}^{-1} \mathrm{yr}^{-1}\right)\end{array}$ & $\begin{array}{l}\text { Ridge to } \\
\text { fire } \\
\text { boundary }\end{array}$ & $\begin{array}{l}\text { Ridge to } \\
\text { fire } \\
\text { boundary }\end{array}$ & $\begin{array}{l}\text { Ridge to } \\
\text { R1 }\end{array}$ & $\begin{array}{l}\text { Ridge to } \\
\text { R1 }\end{array}$ & $\begin{array}{l}\text { Ridge to } \\
\text { R2 }\end{array}$ & $\begin{array}{l}\text { Ridge to } \\
\text { R2 }\end{array}$ & $\begin{array}{l}\text { R1 to } \\
\text { boundary }\end{array}$ & $\begin{array}{l}\text { R1 to } \\
\text { boundary }\end{array}$ & $\begin{array}{l}\text { R2 to } \\
\text { boundary }\end{array}$ \\
\hline & $\begin{array}{l}\text { Area } \\
\text { (ha) }\end{array}$ & $\begin{array}{l}\text { Ratio } \\
(\%)\end{array}$ & $\begin{array}{l}\text { Area } \\
\text { (ha) }\end{array}$ & $\begin{array}{l}\text { Ratio } \\
(\%)\end{array}$ & $\begin{array}{l}\text { Area } \\
\text { (ha) }\end{array}$ & $\begin{array}{l}\text { Ratio } \\
(\%)\end{array}$ & $\begin{array}{l}\text { Area } \\
\text { (ha) }\end{array}$ & $\begin{array}{l}\text { Ratio } \\
(\%)\end{array}$ & $\begin{array}{l}\text { Area } \\
\text { (ha) }\end{array}$ \\
\hline Deposition & 1.48 & 10.25 & 0.15 & 11.39 & 0.81 & 7.47 & 0.15 & 16.79 & 0.39 \\
\hline $0-0.25$ & 2.54 & 17.55 & 0.55 & 41.96 & 0.96 & 8.84 & 0.14 & 15.05 & 1.21 \\
\hline $\begin{array}{l}0.25- \\
1.0\end{array}$ & 0.85 & 5.85 & 0.03 & 2.09 & 0.68 & 6.31 & 0.04 & 4.62 & 0.15 \\
\hline $1.0-2.0$ & 0.79 & 5.48 & 0.04 & 3.01 & 0.59 & 5.44 & 0.04 & 4.13 & 0.09 \\
\hline $2.0-4.0$ & 1.04 & 7.18 & 0.05 & 3.5 & 0.76 & 6.96 & 0.07 & 7.82 & 0.14 \\
\hline$>4.0$ & 7.75 & 53.67 & 0.5 & 38.06 & 7.06 & 64.98 & 0.46 & 51.6 & 0.19 \\
\hline $\begin{array}{l}\text { Ave. } \\
\text { soil } \\
\text { loss } \\
(\mathrm{Mg} \\
\mathrm{ha}^{-1} \\
\left.\mathrm{yr}^{-1}\right)\end{array}$ & 25.33 & 25.33 & 28.03 & 28.03 & 36.38 & 36.38 & 16.05 & 16.05 & -0.06 \\
\hline
\end{tabular}

Table 6. Single event runoff, precipitation, erosion rates and sediment delivery estimated by ERMiT for the postfire BAER analysis (Young, 2016).

\begin{tabular}{llll}
\hline ERMiT Hillslope Estimates & ERMiT Hillslope Estimates & ERMiT Hillslope Estimates \\
\hline 2-year event & 5 -year event & 10 -year event
\end{tabular}




\begin{tabular}{llll}
\hline & ERMiT Hillslope Estimates & ERMiT Hillslope Estimates & ERMiT Hillslope Estimates \\
\hline Runoff $(\mathrm{mm})$ & 17.02 & 29.21 & 37.34 \\
Precip $(\mathrm{mm})$ & 44.20 & 90.68 & $35.31^{+}$ \\
Ave. Erosion Rate $\left(\mathrm{Mg} \mathrm{ha}^{-1}\right)$ & 0.22 & 6.15 & 14.76 \\
Max. Erosion Rate $\left(\mathrm{Mg} \mathrm{ha}^{-1}\right)$ & 0.85 & 29.83 & 52.51 \\
Erosion Production $(\mathrm{Mg})$ & 36.18 & 257.45 & 538.0 \\
\hline
\end{tabular}

+ Runoff is greater than precipitation because of snowmelt on this predicted March runoff event

\section{Figure Legends}

Figure 1. The location and topography of the study site represented by LiDAR DEM

Figure 2. Simulated sediment yield after the wildfire

Figure 3 . Road related sub-catchment delineation

Figure 4. Flow length as influenced by road segments

Figure 5. Simulated onsite soil loss for the post-fire condition

Figure 6. The relationship between average onsite soil loss rate and downslope for a) distance from the ridgetop, b) downhill from road 1 and c) downhill from road 2.

Figure 7. Predicted soil loss rate along a hillslope passing over a road segment. A negative "soil loss" is the way the WEPP output describes deposition.

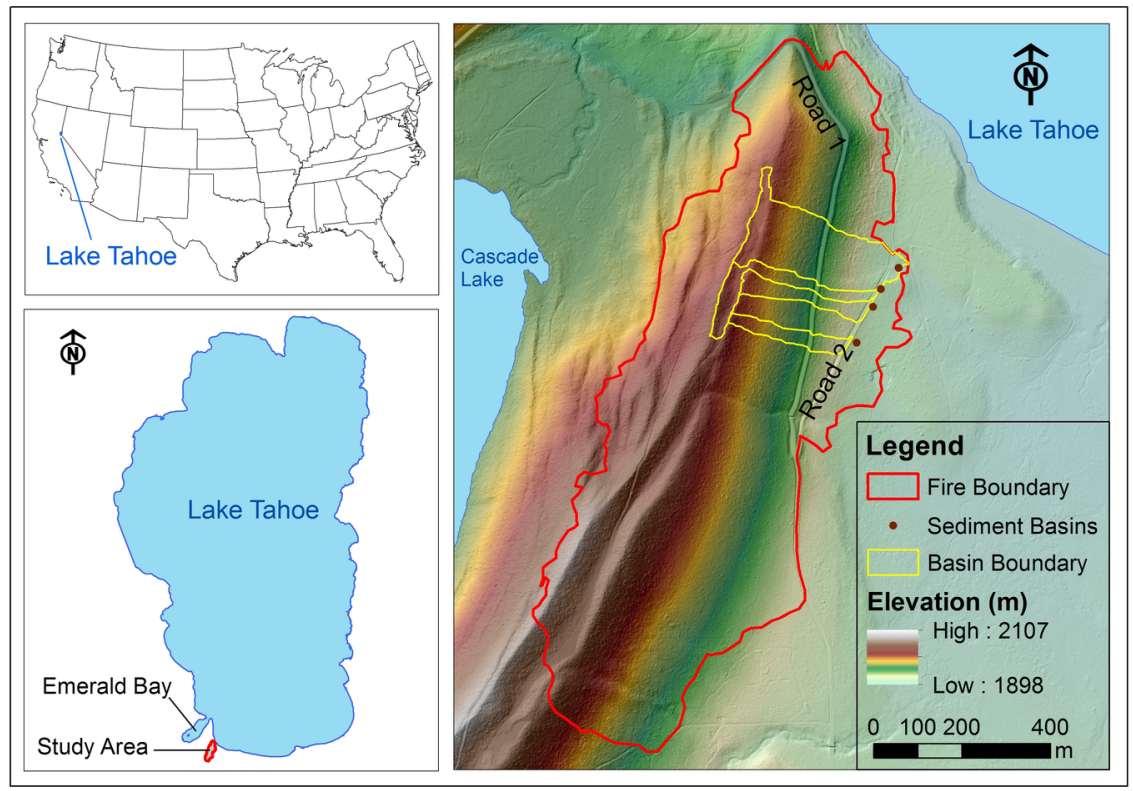




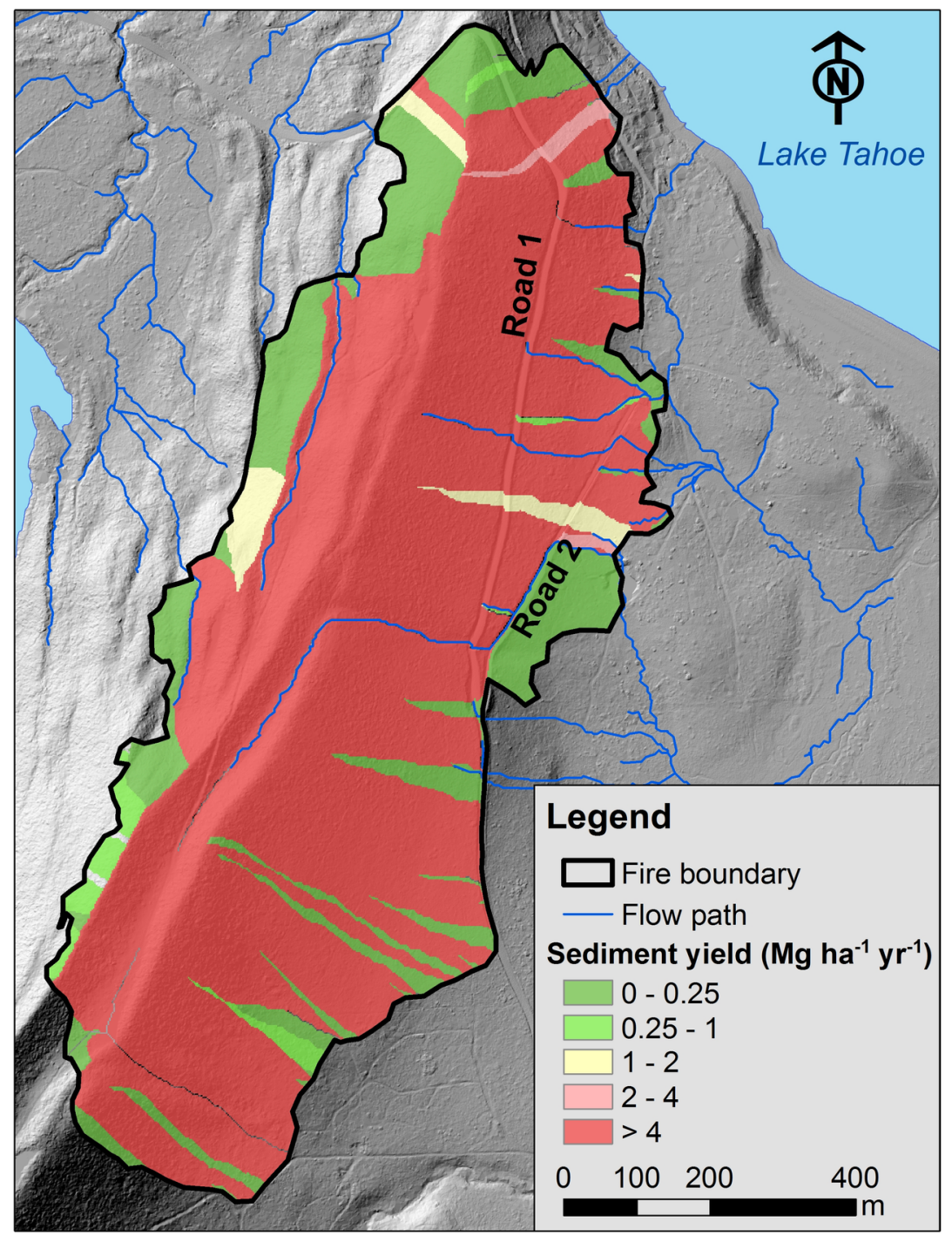




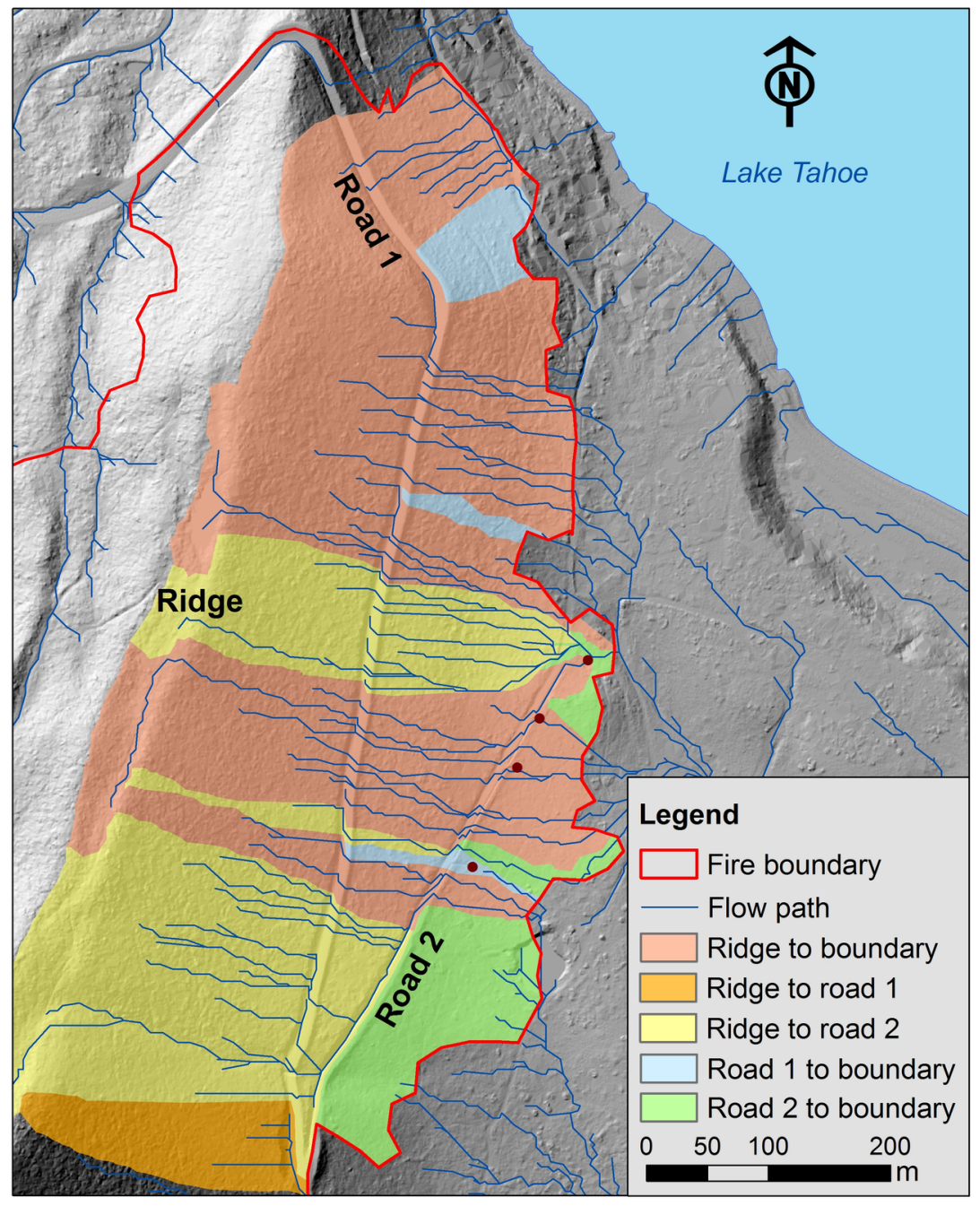




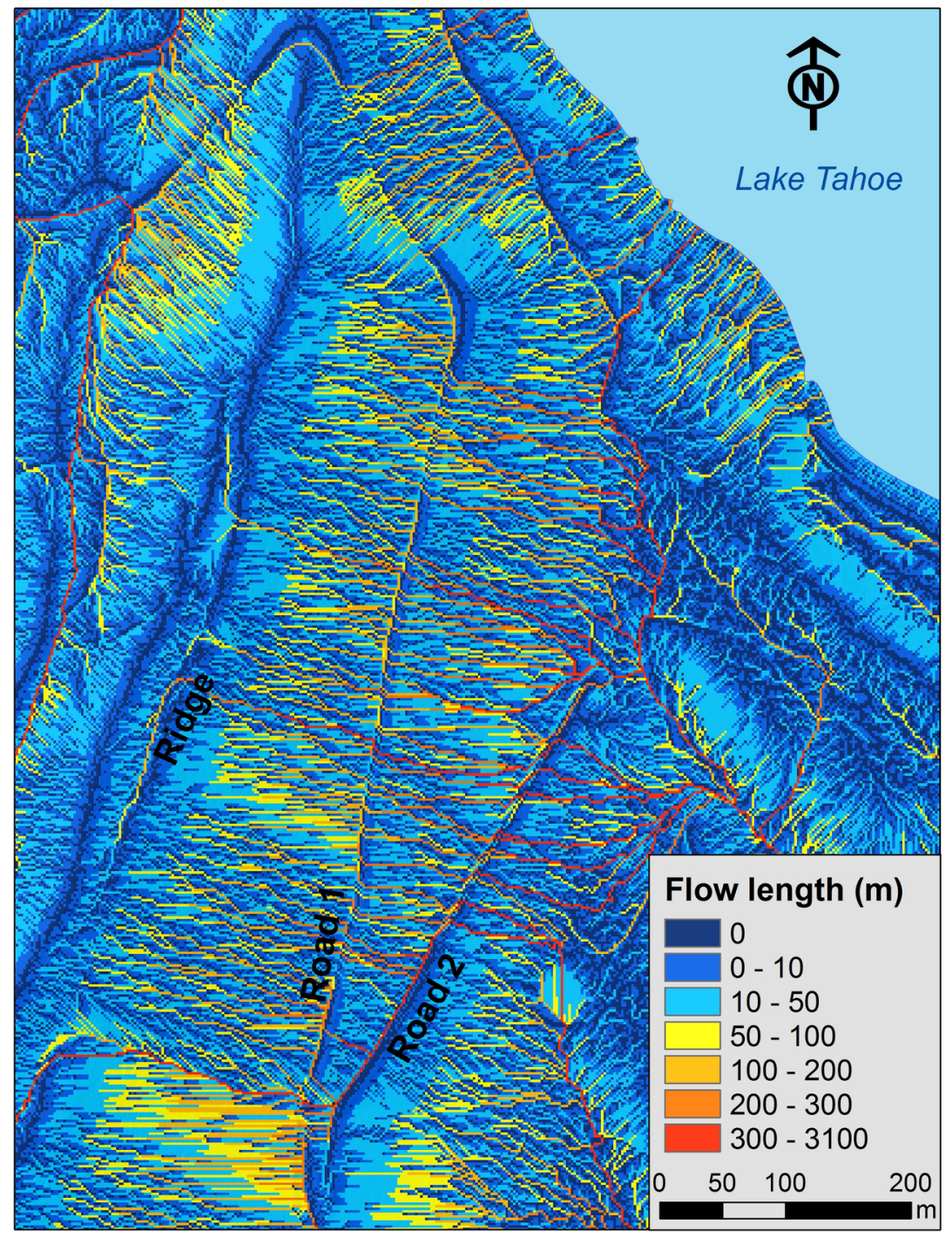



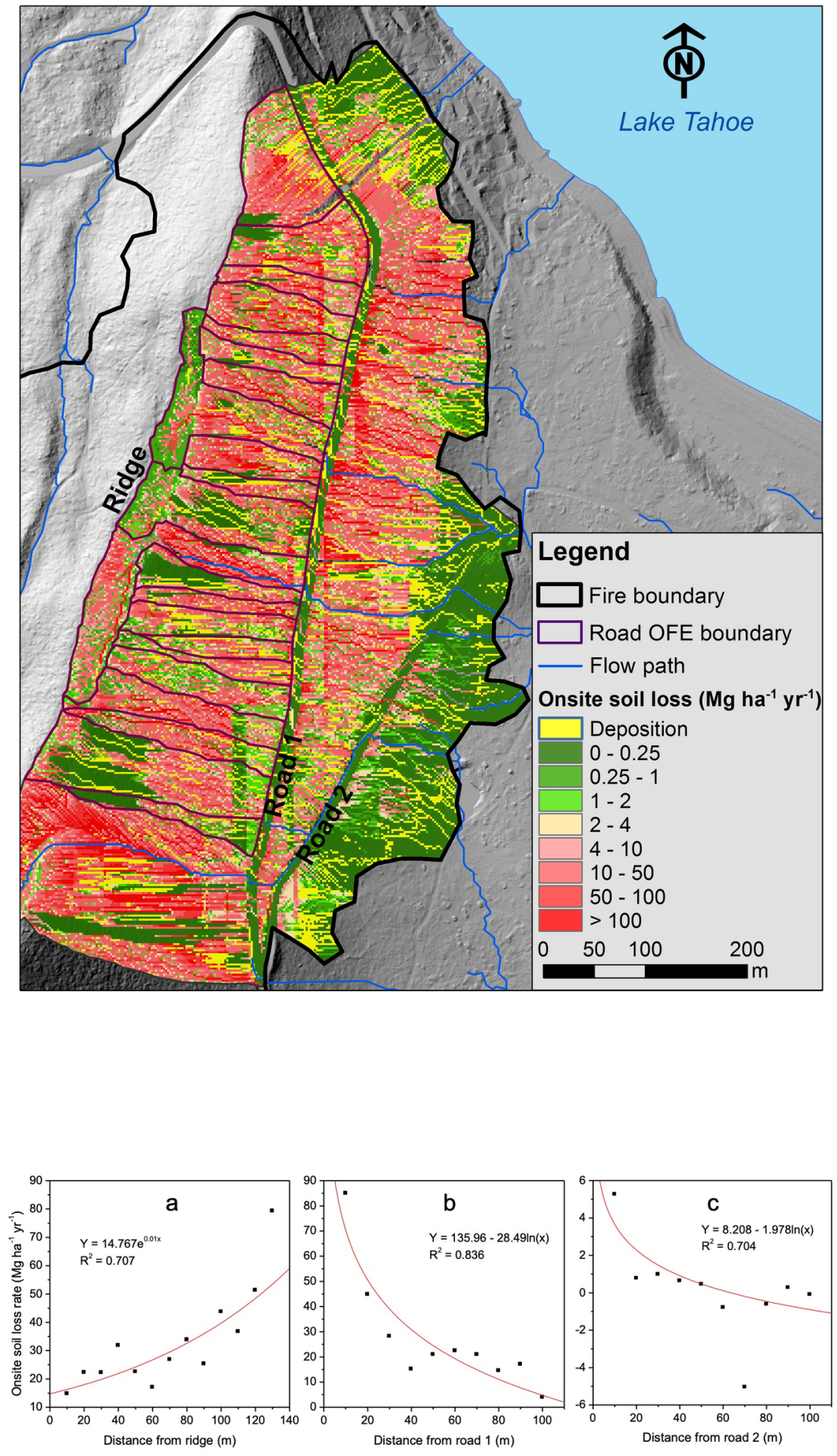


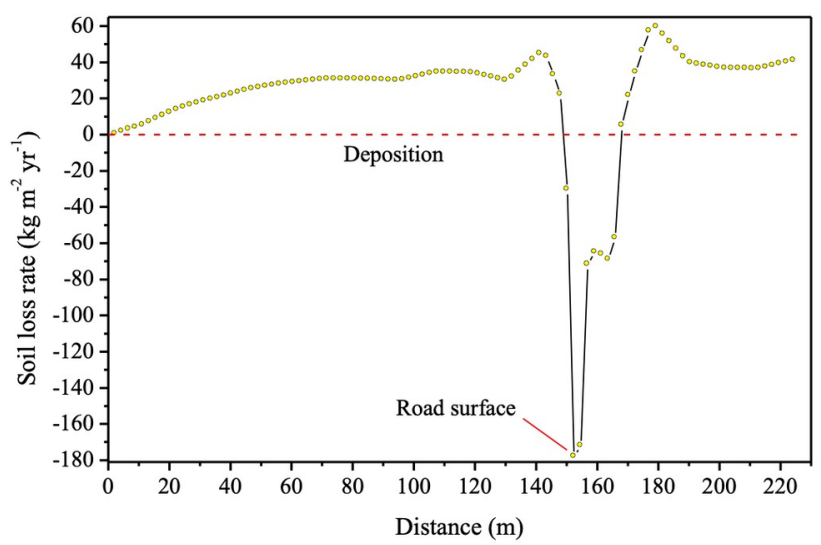

